\title{
Gambaran Kadar Hemoglobin pada Ibu Hamil Trimester III di Rumah Sakit Robert Wolter Mongisidi Manado
}

\author{
Selfesina Sikoway, ${ }^{1}$ Yanti Mewo, ${ }^{2}$ Youla Assa $^{2}$
}

\author{
${ }^{1}$ Program Studi Pendidikan Dokter Fakultas Kedokteran Universitas Sam Ratulangi Manado \\ ${ }^{2}$ Bagian Biokimia Fakultas Kedokteran Universitas Sam Ratulangi Manado \\ Email: selfesina97sikoway@gmail.com
}

\begin{abstract}
Hemoglobin $(\mathrm{Hb})$ is a parameter used to determine anemia prevalence. The average level of normal $\mathrm{Hb}$ at the end of pregnancy is around $12.5 \mathrm{~g} / \mathrm{dL}$, meanwhile, aproximately $5 \%$ of pregnant women have $\mathrm{Hb}$ level less than $11.0 \mathrm{~g} / \mathrm{dL}$. To date, $\mathrm{Hb}$ level below $11.0 \mathrm{~g} / \mathrm{dL}$ especially at the end of pregnancy should be considered as an abnormal phenomenon and is usually caused by iron deficiency and not by hypervolemia which is commonly found in pregnancy. This study was aimed to determine the hemoglobin level of third semester pregnant women in Robert Wolter Mongisidi Hospital Manado. This was a descriptive study with a cross sectional design. Subjects were 39 third semester pregnant women who visited the Obstetric Department of Robert Wolter Mongisidi Hospital and fulfilled the inclusion criteria. The results showed that 25 subjects $(64.1 \%)$ had low hemoglobin levels and 14 subjects (35.9\%) had normal level of hemoglobin. In conclusion, most third semester pregnant women had low hemoglobin levels.
\end{abstract}

Keywords: hemoglobin rate, third trimester pregnant women, anemia

\begin{abstract}
Abstrak: Hemoglobin $(\mathrm{Hb})$ darah merupakan parameter yang digunakan untuk menetapkan prevalensi anemia. Nilai normal $\mathrm{Hb}$ pada akhir kehamilan rata-rata $12,5 \mathrm{~g} / \mathrm{dL}$, dan sekitar $5 \%$ wanita hamil konsentrasinya kurang dari $11,0 \mathrm{~g} / \mathrm{dL}$. Nilai $\mathrm{Hb}$ dibawah $11,0 \mathrm{~g} / \mathrm{dL}$ terutama pada akhir kehamilan perlu dianggap abnormal dan biasanya disebabkan oleh defisiensi besi dan bukan karena hipervolemia yang umumnya ditemukan pada kehamilan. Penelitian ini bertujuan untuk mengetahui kadar hemoglobin pada ibu hamil trimester III di Rumah Sakit Robert Wolter Mongisidi Manado. Jenis penelitian ialah deskriptif dengan menggunakan desain potong lintang. Subyek penelitian ialah 39 ibu hamil trimester III yang berkunjung di Poliklinik Kebidanan di Rumah Sakit Robert Wolter Mongisidi Manado yang memenuhi kriteria inklusi. Hasil penelitian menunjukkan 25 subyek $(64,1 \%)$ memiliki kadar hemoglobin rendah dan 14 subyek $(35,9 \%)$ memiliki kadar hemoglobin normal. Simpulan penelitian ini ialah sebagian besar ibu hamil trimester III memiliki kadar hemoglobin rendah.
\end{abstract}

Kata kunci: kadar hemoglobin, ibu hamil trimester III, anemia

\section{PENDAHULUAN}

Saat hamil kebutuhan oksigen dalam tubuh meningkat sehingga memicu peningkatan produksi eritropoietin. Akibatnya, volume plasma bertambah dan sel darah merah (eritrosit) meningkat. Peningkatan volume plasma terjadi dalam jumlah yang lebih besar jika dibandingkan dengan peningkatan eritrosit sehingga terjadi penurunan konsentrasi hemoglobin akibat hemodilusi. Ekspansi volume plasma merupakan penyebab anemia fisiologi pada kehamilan. ${ }^{1}$

Hemoglobin $(\mathrm{Hb})$ darah merupakan parameter yang digunakan untuk menetapkan prevalensi anemia. ${ }^{2}$ Volume plasma yang bertambah besar menyebabkan konsentrasi hemoglobin agak berkurang selama kehamilan. Akibatnya, kekentalan darah secara keseluruhan berkurang. Nilai normal $\mathrm{Hb}$ pada akhir kehamilan rata-rata 12,5 $\mathrm{g} / \mathrm{dL}$, dan sekitar 5\% wanita hamil memiliki kadar Hb kurang dari 11,0 g/dL. Nilai Hb di 
bawah 11,0 g/dL terutama pada akhir kehamilan perlu dianggap abnormal dan biasanya disebabkan oleh defisiensi besi dan bukan karena hipervolemia kehamilan. ${ }^{3}$

Anemia dalam kehamilan masih menjadi masalah klinis yang sering dijumpai dengan prevalensi rerata $35-75 \%$ di negara berkembang. ${ }^{4}$ Anemia yang terjadi pada wanita hamil cenderung terjadi karena banyaknya wanita yang memulai kehamilan dengan cadangan makanan yang kurang dan pada saat sebelum hamil sudah mengalami anemia. Ibu hamil membutuhkan asupan zat besi yang lebih banyak dibandingkan saat sebelum hamil. Asupan makanan yang tidak adekuat menyebabkan zat besi yang tersedia tidak mencukupi untuk sintesis hemoglobin (Hb) karena defisiensi besi dalam makanan. Kekurangan zat besi akan mengakibatkan kecepatan pembentukan $\mathrm{Hb}$ dan konsentrasinya dalam peredaran darah menurun sehingga menyebabkan anemia pada ibu hamil. ${ }^{5}$

Anemia yang terjadi pada trimester III cenderung lebih banyak karena kebutuhan akan zat besi yang meningkat sesuai usia kehamilan sedangkan simpanan zat besi dalam tubuh tidak mencukupi sehingga banyak ibu hamil trimester III yang mengalami anemia defisiensi besi kecuali jika ibu hamil tersebut diberikan suplemen zat besi. ${ }^{6}$ Menurut laporan World Health Organization (WHO) 2005 terdapat 52\% ibu hamil mengalami anemia di negara berkembang. Di Indonesia tahun 2010 dilaporkan bahwa dari sekitar 4 juta ibu hamil, separuhnya mengalami anemia gizi dan satu juta lainnya mengalami kekurangan energi kronis. ${ }^{7}$ Survei Kesehatan Rumah Tangga (SKRT) melaporkan bahwa prevalensi anemia pada ibu hamil di Indonesia tahun 2004 ialah 40,1\% dan menurut Riset Kese-hatan Dasar (Riskesdas) pada tahun 2007 turun menjadi $24,5 \%{ }^{8}$ Berdasarkan hasil Riskesdas tahun 2013, prevalensi anemia pada ibu hamil di Indonesia naik menjadi $37,1 \% .{ }^{9}$ Keadaan ini mengindikasikan bahwa anemia defisiensi zat besi masih menjadi masalah kesehatan masyarakat. Mengingat besarnya dampak buruk anemia defisiensi zat besi pada wanita hamil dan janin, maka diperlukan perhatian yang cukup terhadap masalah ini.

Berdasarkan hasil survei di ruangan Poli Kebidanan Rumah Sakit Robert Wolter Mongisidi Teling, jadwal pemeriksaan pada ibu hamil dilakukan 5 kali dalam seminggu, yakni pada hari Senin-Jumat. Data yang didapatkan pada 3 bulan terakhir yaitu Juni -Agustus 2018 memperlihatkan bahwa kunjungan ibu hamil sebanyak 175 orang dan ibu hamil trimester III sebanyak 146 orang. Dari jumlah tersebut, data ibu hamil yang berisiko terkena anemia defisiensi besi belum teridentifikasi. Hal ini mendorong penulis untuk meneliti kadar hemoglobin pada ibu hamil trimester III di Rumah Sakit Robert Wolter Mongisidi Manado.

\section{METODE PENELITIAN}

Penelitian ini dilaksanakan pada bulan Juli sampai Desember tahun 2018. Jenis penelitian ini ialah deskriptif dengan menggunakan desain potong lintang. Pemilihan sampel ini dilakukan pada ibu hamil trimester III yang berkunjung di poliklinik kebidanan di Rumah Sakit Robert Wolter Mongisidi Manado dan didapatkan 39 subyek yang memenuhi kriteria inklusi.

Pemeriksaan kadar hemoglobin diambil melalui darah vena (fossa cubiti) oleh petugas laboratorium Rumah Sakit Robert Wolter Mongisidi Manado. Data tersebut diolah menggunakan program Microsoft Office Word 2016 dan Microsoft Office Excel 2016.

\section{HASIL PENELITIAN}

Populasi penelitian ini berjumlah $87 \mathrm{ibu}$ hamil trimester III dengan usia kehamilan 28-40 minggu dan yang memenuhi kriteria inklusi berjumlah 39 orang sebagai subyek penelitian. Pada penelitian ini didapatkan response rate sebesar $44,83 \%$.

Berdasarkan kadar hemoglobin menurut patokan nilai normal pada laboratorium Rumah Sakit Robert Wolter Mongisidi Kota Manado yaitu 11,7-15,5 g/dL, maka didapatkan dari 39 subyek sebanyak 64,1\% dengan kadar $\mathrm{Hb}$ di bawah batas normal dan 35,9\% dalam batas normal (Tabel 1). Dari $64,1 \%$ dengan kadar $\mathrm{Hb}$ di bawah normal, terdapat sekitar $84 \%$ yang tidak mengon- 
sumsi preparat besi dan $16 \%$ yang mengonsumsi preparat besi, sedangkan dari $35,9 \%$ dengan kadar $\mathrm{Hb}$ dalam batas normal terdapat $64,3 \%$ yang tidak mengonsumsi preparat besi dan $35,7 \%$ yang mengonsumsi preparat besi.

Berdasarkan hasil penelitian ini, didapatkan nilai standar deviasi sebesar \pm 1 , nilai mean $11,1 \mathrm{mg} / \mathrm{dL}$, nilai median 11,2 $\mathrm{mg} / \mathrm{dL}$, nilai modus $10,7 \mathrm{mg} / \mathrm{dL}$, nilai minimum $8,6 \mathrm{mg} / \mathrm{dL}$ dan nilai maksimum 12,9 $\mathrm{mg} / \mathrm{dL}$.

Tabel 1. Distribusi frekuensi subyek penelitian berdasarkan kadar hemoglobin

\begin{tabular}{ccc}
\hline $\begin{array}{c}\text { Kadar } \\
\text { hemoglobin }\end{array}$ & $\begin{array}{c}\text { Jumlah } \\
(\mathbf{n})\end{array}$ & $\begin{array}{c}\text { Persentase } \\
(\mathbf{\%})\end{array}$ \\
\hline Rendah & 25 & 64,1 \\
Normal & 14 & 35,9 \\
Tinggi & - & - \\
Total & 39 & 100 \\
\hline
\end{tabular}

\section{BAHASAN}

Hasil penelitian ini mendapatkan dari 39 subyek penelitian terdapat sekitar 25 subyek $(64,1 \%)$ dengan kadar hemoglobin yang rendah $<11,7 \mathrm{~g} / \mathrm{dL}$. Hasil penelitian ini tidak sejalan dengan penelitian yang dilakukan oleh Andriyani ${ }^{10}$ di wilayah kerja Puskesmas Danurejan II yang mendapatkan dari 30 sampel yang diteliti, $60 \%$ yang tidak mengalami anemia, $36,7 \%$ yang mengalami anemia ringan, dan $3,3 \%$ yang mengalami anemia sedang. Responden yang mengalami anemia dikarenakan responden tidak mengonsumsi preparat besi. Demikian pula penelitian yang dilakukan oleh Isviani ${ }^{11} \mathrm{di}$ wilayah kerja Puskesmas Ciputat yang melaporkan bahwa dari 26 sampel terdapat $30,8 \%$ yang mempunyai kadar hemoglobin di bawah normal dan $69,2 \%$ yang mempunyai kadar hemoglobin normal. Responden yang mempunyai kadar hemoglobin normal itu dikarenakan sebagian besar mengonsumsi preparat besi. Hal ini menjelaskan bahwa kadar hemoglobin dipengaruhi oleh beberapa faktor antara lain: mengonsumsi preparat besi dan zat makanan lain yang mengandung besi. ${ }^{12}$

Pada penelitian ini sebagian besar subyek yang memiliki kadar hemoglobin di bawah normal tidak mengonsumsi preparat besi. Sesuai dengan teori diharapkan kadar hemoglobin dapat normal pada ibu hamil trimester III yang mendapatkan tambahan konsumsi preparat besi karena kebutuhan zat besi yang meningkat pada kehamilan dan tidak dapat dipenuhi hanya dengan makanan saja, meskipun makanan yang dimakan tersebut mengandung zat besi yang cukup banyak. ${ }^{13}$ Pemberian preparat besi merupakan cara penanggulangan yang diberikan kepada ibu hamil untuk menanggulangi atau mencegah anemia akibat kekurangan zat besi. Anjuran pemerintah untuk ibu hamil yaitu mengonsumsi 1 tablet per hari selama kehamilan atau minimal sebanyak 90 tablet selama kehamilan.

Berdasarkan hasil penelitian ini, kadar hemoglobin yang normal didapatkan pada $35,9 \%$ subyek penelitian karena subyek tersebut mengonsumsi preparat besi dan makanan yang mengandung zat besi. Besi berfungsi untuk pembentukan hemoglobin, dan kadar hemoglobin yang rendah pada kehamilan dapat mengakibatkan dampak buruk pada ibu dan janin. ${ }^{14,15}$ Oleh karena itu, pada kehamilan kadar hemoglobin harus terus dijaga dan dikontrol supaya tidak terjadi hal-hal yang tidak diinginkan yaitu secara teratur mengonsumsi preparat besi, dan sumber zat besi lainnya yang terkandung dalam makanan.

Konsumsi preparat besi contohnya ferrous sulphate dan makanan yang mengandung zat besi oleh subyek yang berisiko merupakan metode terbaik untuk menangani anemia defisiensi besi. ${ }^{11}$ Jika dilihat dari hasil penelitian ini kadar hemoglobin yang normal didapatkan pada subyek yang mengonsumsi preparat besi.

Keterbatasan penelitian ini yaitu tidak dapat mengambil seluruh populasi pada hari tertentu karena alasan administrasi. Oleh karena itu sebaiknya tersedia data kadar hemoglobin pada subyek dari trimester I dan II. Selain itu, pada penelitian ini hanya diteliti kadar hemoglobin saja tanpa mengevaluasi faktor-faktor yang dapat memengaruhi kadar hemoglobin. 


\section{SIMPULAN}

Sebagian besar ibu hamil trimester III di Rumah Sakit Robert Wolter Mongisidi Manado mempunyai kadar hemoglobin rendah.

Bagi responden dengan kadar hemoglobin yang rendah sebaiknya mengonsumsi preparat besi secara teratur dan bagi responden dengan kadar hemoglobin normal sebaiknya tetap menjaga asupan preparat besi dan zat gizi lainnya. Bagi peneliti selanjutnya disarankan untuk meneliti faktor-faktor yang memengaruhi kadar hemoglobin ibu hamil.

\section{Ucapan Terima Kasih}

Disampaikan terima kasih kepada seluruh pasien yang memeriksakan diri di Poliklinik Kebidanan Rumah Sakit Robert Wolter Mongisidi Manado, Laboratorium Rumah Sakit Robert Wolter Mongisidi Manado, dan semua pihak yang ikut terlibat dalam penelitian ini.

\section{Konflik Kepentingan}

Penulis menyatakan tidak terdapat konflik kepentingan dalam studi ini.

\section{DAFTAR PUSTAKA}

1. Prawirohardjo S. Ilmu Kebidanan (4th ed). Jakarta: Bina Pustaka Sarwono Prawirohardjo, 2008; p. 775-80.

2. Supariasa IDN, Bachyar B, Ibnu F. Penilaian Status Gizi. Jakarta: EGC, 2002; p. 145.

3. Cunningham FG, Leveno KJ, Bloom SL, Hauth J, Rouse D, Spong CJ. Obstetri Williams Vol 1 (23rd ed). Pendit BU, alih bahasa. Setia R, editor. Jakarta: EGC, 2010; p. 120.

4. Bakta IM. Pendekatan terhadap pasien anemia. In: Sudoyo AW, Setiyohadi B, Alwi I, Simadibrata M, Setiati S, editors. Buku Ajar Ilmu Penyakit Dalam (5th ed). Jakarta Pusat: Interna Publishing, 2006; p. 109-15.

5. Nurhidayati A. Hubungan asupan nutrisi dengan kadar $\mathrm{Hb}$ pada ibu hamil di BPS Suratini Suwarno Surakarta. Jurnal Kesehatan Kusuma Husada. 2014; 5(1):
21-7.

6. Rizki F, Lipoeto NI, Ali H. Hubungan supplementasi tablet $\mathrm{Fe}$ dengan kadar hemoglobin pada ibu hamil trimester III di Puskesmas Air Dingin Kota Padang. Jurnal Kesehatan Andalas. 2017;6(3): 502-6.

7. Patimah S, Hadju V, Bahar B, Abdullah Z. Pola konsumsi dan kadar hemoglobin pada ibu hamil di Kabupaten Maros Sulawesi Selatan. Makara Kesehatan. 2011;15(1): 31-6.

8. Elsy N. Faktor-faktor yang berhubungan dengan kejadian anemia pada ibu hamil trimester III di Wilayah kerja Puskesmas Air Dingin Kota Padang tahun 2012 [Tesis]. Padang: Universitas Andalas; 2014.

9. Badan Penelitian dan Pengembangan Kesehatan Kementerian Kesehatan RI. Riskesdas (Riset Kesehatan Dasar). Jakarta, 2013.

10. Andriyani A. Gambaran kadar hemoglobin pada ibu hamil trimester III di wilayah kerja Puskesmas Danurejan II [Karya Tulis Ilmiah]. Yogyakarta: Sekolah Tinggi Ilmu Kesehatan Jenderal Achmad Yani; 2017.

11. Isviani H. Gambaran kadar hemoglobin pada ibu hamil di wilayah kerja Puskesmas Ciputat [Skripsi]. Jakarta: Universitas Islam Negeri Syarif Hidayatullah; 2017.

12. Wiraprasidi IPA, Kawengian SE, Mayulu N. Faktor-faktor yang berhubungan dengan kadar hemoglobin pada ibu hamil di Puskesmas Lolak. eBiomedik. 2017; $5(2)$.

13. Fanny L, Mustamin H, Dewi T, Kartini S. Pengaruh pemberian tablet $\mathrm{Fe}$ terhadap kadar hemoglobin ibu hamil di Puskesmas Tamamaung tahun 2011. Jurnal Media Gizi Pangan 2012;13(1):7-11.

14. Guyton AC, Hall JE. Buku Ajar Fisiologi Kedokteran (11th ed). Irawati, Ramadhani D, Indriyani F, Dany F, Nuryanto I, Rianti SSP et al, alih bahasa. Rachman LY, Hartanto H, Novrianti A, Wulandari N, editors. Jakarta: EGC, 2007.

15. Manuaba IBG. Obstetri Umum. In: Penuntun Kepaniteraan Klinik Obstetri dan Ginekologi. Jakarta: EGC, 2003. 